\section{Production, Isolation, and Character- ization of Rabbit Anti-Idiotypic Antibodies Directed against Human Antithyrotrophin Receptor Antibodies}

\author{
James R. Baker, Jr., Yvonne G. Lukes, \\ and Kenneth D. Burman \\ Transplant Immunology and Endocrine-Metabolic Services, \\ Departments of Clinical Investigation and Medicine, Walter Reed \\ Army Medical Center, Washington, District of Columbia 20307; \\ Department of Medicine, The Uniformed Services University of \\ the Health Sciences, Bethesda, Maryland 20014
}

bstract. Previous studies have shown that antiidiotypic antibodies can be developed in vivo through animal immunization with idiotype, and that these antibodies can be isolated from other anti-immunoglobulin antibodies by affinity purification. These techniques have relied on large amounts of idiotype, which were produced either by hyperimmunization or by monoclonal antibodies, to serve as the affinity adsorbent. In the present study, we produced anti-idiotypic antibodies to human anti-thyroid-stimulating hormone (TSH) receptor antibodies by first injecting rabbits with (TSH receptor purified) IgG from Graves' patients. The resulting antiserum was then adsorbed with Sepharose-coupled TSH in an attempt to specifically bind and isolate the anti-idiotype. The antibody obtained from this process was shown to bind specifically to TSH receptor-binding antibodies from Graves' patients, and this binding could be inhibited by $56 \%$ with the addition of $10^{-4} \mathrm{M}$ TSH but not by HCG $\left(10^{-2} \mathrm{M}\right)$. The anti-idiotype also bound to $\mathrm{TSH}$, and this binding could be specifically inhibited by receptor-purified

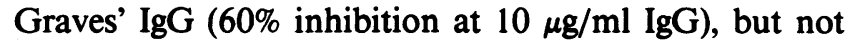
by IgG from normal subjects (no inhibition at $50 \mu \mathrm{g} / \mathrm{ml}$ IgG). In a TSH receptor binding assay, the anti-idiotype could inhibit TSH receptor binding in Graves' sera at a 1,000-fold lower concentration than could anti-kappa/

The opinions or assertions contained herein are the private views of the authors and are not to be construed as official or reflecting the views of the Department of the Army or the Department of Defense.

Address reprint requests to Dr. Baker, Department of Clinical Investigation, at the Walter Reed Army Medical Center.

Received for publication 12 January 1984 and in revised form 18 April 1984.

The Journal of Clinical Investigation, Inc.

Volume 74, August 1984, 488-495 lambda antiserum; the anti-idiotypic antiserum also inhibited in vitro TSH-mediated adenylate cyclase stimulation at an IgG concentration of $5 \mu \mathrm{g} / \mathrm{ml}$, while heterologous anti-TSH antisera and normal IgG at similar concentrations had no effect. Finally, despite being generated against a single patient's TSH receptor binding antibody, the anti-idiotype was able to block TSH receptor binding in the serum of six other Graves' patients, thus suggesting that there may be conformational conservation in the antigen that is recognized by different individuals' TSH receptor-binding immunoglobulins.

\section{Introduction}

Graves' disease is an autoimmune disorder that is characterized by thyroid gland stimulation which is due to antibodies that bind to the thyroid-stimulating hormone (TSH) receptor (1-3). While the mechanism by which these TSH receptor-binding antibodies (Rbabs) mimic TSH action is unknown, these antibodies have been shown to bind by their $F(a b)$ region (4), and probably recognize the receptor as an antigen through their hypervariable, antigen-combining site.

The mechanism of autoantibody-receptor interaction, such as that noted in Graves' disease, has been of interest in studying the development of autoimmunity. Recent studies that used anti-idiotypic (anti-id) antibodies as probes (5-7) have shown that a small fraction of anti-ids appear to be internal images of the idiotype, combining sites and as a result having conformational similarity to antigen, and binding to idiotype competitively with antigen. When the antigen is a hormone receptor, as in the case of beta receptor antibodies $(8,9)$, the anti-ids, by

1. Abbreviations used in this paper: anti-id, anti-idiotypic antibody; GPF, guinea pig fat cell membranes; HCG, human chorionic gonadotropin; PNP, $P$-nitrophenylphosphate; PBST, phosphate-buffered saline with $0.05 \%$ Tween 20, pH 7.2; Rbabs, TSH receptor-binding antibodies; TSH, thyroid-stimulating hormone. 
sharing conformational similarity with the beta receptor, will bind beta ligands. However, the extension of this work to other antigens has been limited by the need for large amounts of idiotype, which is produced either by hyperimmunization or monoclonal antibody.

The relevance of anti-idiotypic antibodies in the regulation of antibody-mediated autoimmune disorders also has recently been emphasized. Disease activity in systemic lupus erythematosis has been reported to be inversely related to the presence of anti-id antibodies against anti-DNA antibodies (10). In an attempt to apply similar concepts to Graves' disease, it has been suggested that the antibodies directed against TSH receptors that are observed in Graves' patients may actually be anti-id antibodies to anti-TSH antibodies (11). This implies that an initial step in development of Graves' disease is the formation of antibodies against TSH, and that a small fraction of anti-id is bound to the TSH receptor fortuitously due to the anti-id's conformational similarity to the TSH. While it is logical to assume that both antibodies against the TSH receptor and TSH have conformational similarities, it seems equally likely that the development of antibodies against the TSH receptor is the primary event, and that the anti-TSH antibodies that have been described may actually be anti-id antibodies to the anti-TSH receptor antibodies. Demonstration of such an anti-id might have therapeutic significance $(10,12)$, especially if it bound to many different patients' TSH receptor-binding immunoglobulins. However, previous attempts to demonstrate an antibody to TSH that crossreacts with Graves' IgG have been unsuccessful $(13,14)$.

In the present studies, we have endeavored to demonstrate that (a) anti-id antibodies to human TSH receptor antibodies can be developed in animals, and affinity purified, to be used as a probe for investigations into the function of idiotype; $(b)$ the anti-id antibodies appear to be conformationally similar to TSH receptor, by competitively binding both TSH and Rbabs; and $(c)$ the binding of the anti-id to TSH receptor antibodies from several patients suggests that a similar antigenic determinant or conformation may be involved.

\section{Methods}

Hormones and reagents. Highly purified bovine TSH was a generous gift of Dr. J. G. Pierce, University of California, Los Angeles. Microtiter plates (Immulon 2) were purchased from Dynatech Laboratories, Inc., Dynatech Corp. (Alexandria, VA). Affinity purified, alkaline phosphataseconjugated anti-human IgG (Fc specific) antiserum and $P$-nitrophenylphosphate (PNP) were purchased from Sigma Chemical Co. (St. Louis, MO). Purified human TSH was kindly supplied by the Hormone Distribution Program of the National Pituitary Agency (Baltimore, MD). Affinity-purified goat anti-rabbit IgG, both unconjugated antiserum and alkaline phosphatase conjugate, anti-human kappa, lambda, and $\left(\mathrm{F}\left(\mathrm{ab}^{\prime}\right)_{2}\right.$ antisera, purified human IgG, and purified rabbit IgG were purchased from Cappel Laboratories Inc. (Cochranville, PA). Tween 20 was purchased from Fisher Scientific Co. (Fair Lawn, NJ). Human chorionic gonadotropin (HCG) was purchased from Ayerst Laboratories, Inc. (New
York). Heterologous anti-human TSH was obtained from Hyland Laboratories (Costa Mesa, CA).

Patients. The serum from seven patients with classic laboratory and clinical findings of Graves' disease (15) were chosen for this study. After informed consent was obtained, a 4-ml serum sample was collected from each patient and screened in an enzyme-linked immunosorbent assay for direct, TSH receptor, membrane binding (16), and selected patient sera were also analyzed in a bioassay for $T_{3} / T_{4}$ stimulating capacity (courtesy of Dr. James Peter, Specialty Labs Inc., Los Angeles, CA). The patient who had the highest activity ( $>8 \mathrm{SD}$ above the normal range in both assays) had $60 \mathrm{~cm}$ of blood drawn after informed consent. The serum was separated, aliquoted, and frozen for use in the rabbit immunization and for screening the rabbit antisera. The other patients' sera were also frozen $\left(-4^{\circ} \mathrm{C}\right)$ and aliquoted for use in screening the binding capability of the purified anti-id.

Guinea pig fat cell membrane (GPF) preparation and "receptor purification" of Graves' IgG. Preparation of GPF and TSH receptor-purified immunoglobulin were performed according to the method of Endo et al. (17).

Rabbit immunization procedure. Graves' patient IgG was first pepsin digested to make $F\left(a b^{\prime}\right)_{2}$ fragments. This digest was placed over a staphylococcus protein A Sepharose column to remove nondigested $\mathrm{IgG}$, and the nonadherent fraction was collected. The $F\left(a b^{\prime}\right)_{2}$ fragments were then receptor purified $(16,17)$. This fraction, which contained no detectable Fc fragments by Ouchterlony gel diffusion, was then shown by high performance liquid chromatography not to contain detectable TSH. From this fraction, a $2.5-\mathrm{ml}$ aliquot which contained $\sim 1 \mathrm{mg}$ of protein was removed and mixed with $2.5 \mathrm{ml}$ complete Freund's adjuvant. After obtaining serum samples, New Zealand white rabbits were injected with the Freund's $F\left(a b^{\prime}\right)_{2}$ mixture at four locations on their hindquarters. Rabbits were immunized with $2.5 \mathrm{ml}$ of the $\mathrm{F}\left(\mathrm{ab}^{\prime}\right)_{2}$ concentrate at 1 and 4 wk after the initial injection, and $20-\mathrm{ml}$ blood samples were obtained at 2, 4, and $6 \mathrm{wk}$ after the initial injection. Control rabbits were injected with human myosin under the same protocol.

Affinity purification of the rabbit antiserum. Rabbit antiserum was adsorbed against a column of normal IgG (Cohn fraction II, Hyland Laboratories), and then affinity purified using a bovine TSH affinity column. Both columns were made by coupling the respective proteins to Affi-Gel 10 (Bio-Rad Laboratories, Richmond, CA). $200 \mathrm{mg}$ of normal IgG was added to $20 \mathrm{ml}$ of packed gel for the IgG column and $50 \mathrm{mg}$ of bovine TSH was added to $10 \mathrm{ml}$ of gel for the TSH column. Both were allowed to react for $1 \mathrm{~h}$ at $27^{\circ} \mathrm{C}$ in $0.1 \mathrm{M} \mathrm{NaHCO}_{3}, \mathrm{pH} 8.5$. The gels were then blocked with $1 \mathrm{M}$ ethanolamine (pH 8.0) using $0.1 \mathrm{ml} /$ $\mathrm{ml}$ of gel; coupling efficiency was estimated to be $\sim 90 \%$ for both columns. $50 \mathrm{mg}$ of an $\mathrm{IgG}$ fraction from an immunized rabbit were concentrated to a $5 \mathrm{ml}$ vol, and adjusted to a $150 \mathrm{mM} \mathrm{NaCl}$ concentration. This fraction was then placed on the IgG column $(20-\mathrm{ml}$ bed vol) which was kept at $4^{\circ} \mathrm{C}$. The sample was allowed to equilibrate for $15 \mathrm{~min}$, then a 5-ml aliquot was collected and reapplied to the column. This was repeated three additional times before the column was washed with phosphatebuffered saline (PBS) and $301-\mathrm{ml}$ fractions were collected. These 30 fractions, which contained a total of $25 \mathrm{mg}$ of protein, were stepwise concentrated to $1 \mathrm{ml}$ and dialyzed extensively (overnight, $4^{\circ} \mathrm{C}$ ) against PBS to adjust the $\mathrm{NaCl}$ concentration to $150 \mathrm{mM}$. This $1-\mathrm{ml}$ fraction was then placed on the TSH affinity column (10-ml total bed vol), and flushed through three times with PBS. The column was then washed extensively with PBS to remove nonadherent protein; the IgG was eluted with $3.5 \mathrm{M} \mathrm{NaSCN}$, and a $50-\mathrm{ml}$ fraction was collected. This fraction was dialyzed extensively (overnight, $4^{\circ} \mathrm{C}$ ) against PBS until no evidence of thiocyanate was present on analysis by high performance liquid chro- 
matography. This fraction was concentrated to a rabbit IgG concentration of $20 \mu \mathrm{g} / \mathrm{ml}$ and frozen in aliquots at $-20^{\circ} \mathrm{C}$ until used.

Rabbit IgG assay. The affinity-purified rabbit IgG was assayed for IgG concentration using an adaptation of the double antibody capture enzyme-linked immunosorbent assay technique, as previously published (18).

Human IgG binding assay. Microtiter plate wells were covered with $100 \mu \mathrm{l}$ of a $50-\mu \mathrm{g} / \mathrm{ml}$ solution of Cohn fraction II, normal IgG (Hyland Laboratories) was diluted in PBS, and it was incubated overnight at $4^{\circ} \mathrm{C}$. The plates were then washed once with PBS and were coated with triplicate dilutions of rabbit antiserum. After a 2 -h incubation at $37^{\circ} \mathrm{C}$, the plates were washed three times with phosphate-buffered saline with $0.05 \%$ Tween $20, \mathrm{pH} 7.2$ (PBST) $(0.1 \%)$, and $100 \mu \mathrm{l}$ of a $1: 1,000$ dilution of alkaline phosphatase-conjugated anti-rabbit IgG was added to all wells. After a second, 2-h dilution at $37^{\circ} \mathrm{C}$, the plates were again washed three times with $0.1 \%$ PBST and substrate $(150 \mu \mathrm{l}$ of PNP in diethanolamine buffer, $\mathrm{pH}$ 9.6) was added. The color change was read with an automated spectrophotometer when control samples reached a predetermined value of optical density at $405 \mathrm{~nm}$. Values from each triplicate were then averaged, and a standard deviation was calculated. Inhibitor studies were done in the same manner except that inhibitors were added to the dilutions of rabbit antiserum and co-incubated for $30 \mathrm{~min}$ before being added to the microtiter plates.

TSH binding assay. Microtiter plate wells were coated with human TSH at $10^{-7} \mathrm{I} \mu \mathrm{U} / \mathrm{ml}(100 \mu \mathrm{l} /$ well $)$ and incubated overnight at $4^{\circ} \mathrm{C}$. They were then washed once with PBS, and $100 \mu$ lof PBS with $1 \%$ human serum albumin was added. After incubating for $1 \mathrm{~h}$ at $37^{\circ} \mathrm{C}$, the plates were washed three times with PBST, and samples to be evaluated for TSH binding antibodies were diluted in PBST and placed in the wells in triplicate wells. After a second 1-h incubation, the plates were washed three times with $0.1 \%$ PBST and a 1:1,000 dilution of affinity purified, alkaline phosphatase-labeled, anti-rabbit IgG was added. The plates were then incubated for a final $1-\mathrm{h}$ period at $37^{\circ} \mathrm{C}$, and then washed three times with PBST. Enzyme substrate (PNP in diethanolamine buffer, pH 9.6) was added, and color change was read when control wells reached a predetermined optical density $(405 \mathrm{~nm})$ reading. Inhibitor studies were done in the same manner, except that inhibitors were added to the dilutions of rabbit antiserum and co-incubated for $30 \mathrm{~min}$ before being added to the microtiter plates.

Enzyme-linked membrane (TSH receptor) binding assay and the competitive inhibition of enzyme-linked membrane (TSH receptor) binding assay. These assays were performed as previously described (16). The inhibitor studies were performed by adding the inhibitor to the human sera dilutions immediately before placing them in microtiter plates.

Human sera binding to anti-human $F\left(a b^{\prime}\right)$. Microtiter plate wells were coated with $100 \mu \mathrm{l} \mathrm{of} 2 \mu \mathrm{g} / \mathrm{ml}$ of affinity-purified anti-human $\mathrm{F}\left(\mathrm{ab}^{\prime}\right)_{2}$ that was diluted in PBS, and incubated overnight at $37^{\circ} \mathrm{C}$. Plates were then washed once with PBS, and $100 \mu l$ of $1 \%$ human serum albumin in PBS was added and incubated for $1 \mathrm{~h}$ at $37^{\circ} \mathrm{C}$. The plates were washed three times with $0.1 \%$ PBST and human sera samples were added in triplicate. After a 2 -h incubation at $37^{\circ} \mathrm{C}$, the plates were again washed three times and a 1:1,000 dilution of anti-human IgG that was conjugated to alkaline phosphatase was added. After a final 2-h incubation at $37^{\circ} \mathrm{C}$, the plates were washed three times with $0.1 \%$ PBST and PNP substrate was added. The plates were then read with an automated spectrophotometer. Inhibitor studies were done in the same manner except that inhibitors were incubated with the dilutions of human sera for $30 \mathrm{~min}$ before their addition to the microtiter plates.

Adenylate cyclase assay. This assay was performed according to the method of Kleinmann et al. (19) using human thyroid membranes and a double column purification in order to isolate radioactive cyclic-AMP. Inhibitors were added to samples immediately before addition to membrane. After informed consent, human thyroid glands were obtained at the time of surgery for Graves' disease or multinodular goiter. Membranes were isolated by previously published techniques $(16,17,19)$.

Statistical analysis. Unpaired $t$ tests were used to determine whether values were different between control and maximally inhibited samples.

\section{Results}

Binding capabilities of whole rabbit antiserum. Antiserum from rabbits injected with Graves' IgG that was isolated by receptor precipitation showed significant binding against human TSH and normal human IgG, as well as towards the receptor-purified Graves' IgG to which it had been raised (Fig. 1). The binding to normal IgG was completely suppressible with the addition of normal IgG but the binding to Graves' IgG was only partially (40\%) suppressible by the addition of normal IgG (not shown). After passage over the Sepharose-bound normal IgG column, binding to TSH or Graves' IgG in the void volume was unchanged or increased, but binding to normal IgG was substantially reduced $(P<0.001$, Fig. 1$)$. After passing the void volume from the IgG column over the TSH column, the fraction which bound to TSH and was then eluted still had significant binding to TSH and Graves' IgG, but had no significant binding to normal IgG. It is this fraction which was labeled as rabbit antiid. Control antisera showed no difference in binding from preimmune sera (data not shown). Yield of antibody was about $1 / 500$ of starting $\mathrm{Ig}(100 \mu \mathrm{g}$ from $50 \mathrm{mg})$.

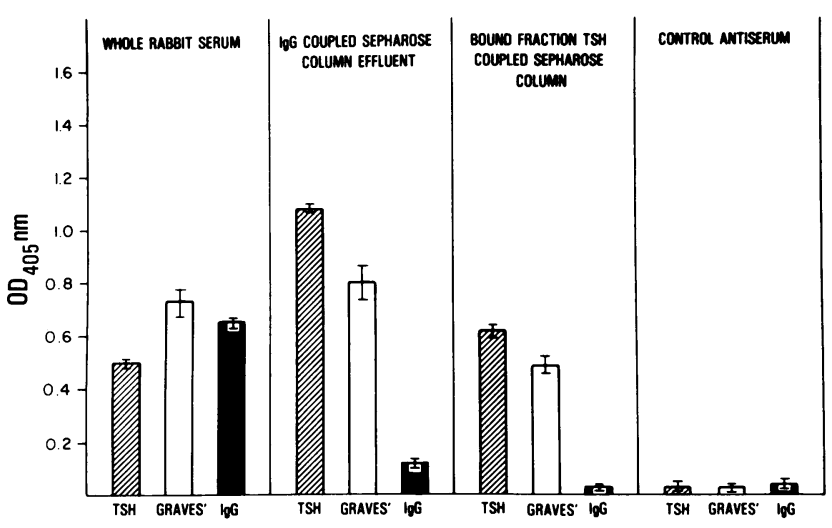

Figure 1. Binding of rabbit antibodies raised against TSH receptorpurified $\mathrm{F}\left(\mathrm{ab} \mathrm{b}_{2}\right)_{2}$ fragments during sequential purification. Binding against human TSH, Graves' patient IgG, and normal IgG was assayed with the rabbit IgG concentration maintained constant at $1 \mu \mathrm{g} /$ $\mathrm{ml}$. Binding is initially noted against all three antigens; however, passage over a heterologous, human IgG affinity column preferentially removes binding to normal IgG. Specific absorption and elution from a TSH column preserves binding to both TSH and Graves' IgG while completely removing binding to normal IgG. Error bars in all figures indicate $\pm 1 \mathrm{SD}$. 
Inhibition of rabbit anti-id binding to TSH by Graves' IgG. Rabbit anti-id at a concentration of $1 \mu \mathrm{g} / \mathrm{ml}$ consistently bound to washed microtiter plates coated with human TSH. The addition of increasing concentrations of receptor-isolated Graves' IgG resulted in significant, progressive inhibition of binding $(P$ $<0.001$, Fig. 2). This ranged from $80 \%$ of control at $500 \mathrm{ng} /$ $\mathrm{ml}$ of receptor-purified Graves' IgG to $40 \%$ at $10 \mu \mathrm{g} / \mathrm{ml}$. In comparison, the addition of receptor protein at a concentration of $2 \mu \mathrm{g} / \mathrm{ml}$ or normal human IgG at $500 \mu \mathrm{g} / \mathrm{ml}$ had no significant effect on the binding of the rabbit anti-id to TSH, which indicated that the inhibition was not due to contaminating receptor or nonspecific protein interactions. Higher concentrations of receptor $(20 \mu \mathrm{g} / \mathrm{ml}$, not shown) did result in inhibition, presumably through competition for TSH binding.

Inhibition of rabbit anti-id binding to Graves' receptor-purified IgG by bovine TSH. Rabbit anti-id at a concentration of $1 \mu \mathrm{g} / \mathrm{ml}$ bound to receptor (purified) IgG that was coated on microtiter plates. The addition of bovine TSH (adequate quantities of human TSH could not be obtained) caused progressive inhibition of binding, up to $54 \%$ of control at a $10^{-4} \mathrm{M}$ concentrations of TSH $(P<0.001$, Fig. 3). In contrast, higher concentrations of $\mathrm{HCG}$, up to $10^{-2} \mathrm{M}$, did not have any effect on the binding, which indicated the specificity of inhibition by TSH.

Inhibition of Graves' serum binding to TSH receptor by rabbit anti-id. The addition of rabbit anti-id to a Graves' patient's serum before the serum was incubated with solid-phase TSH

\section{INHIBITION OF ANTI-Id BINDING TO TSH BY THE ADDITION OF RECEPTOR PURIFIED GRAVES' IgG}

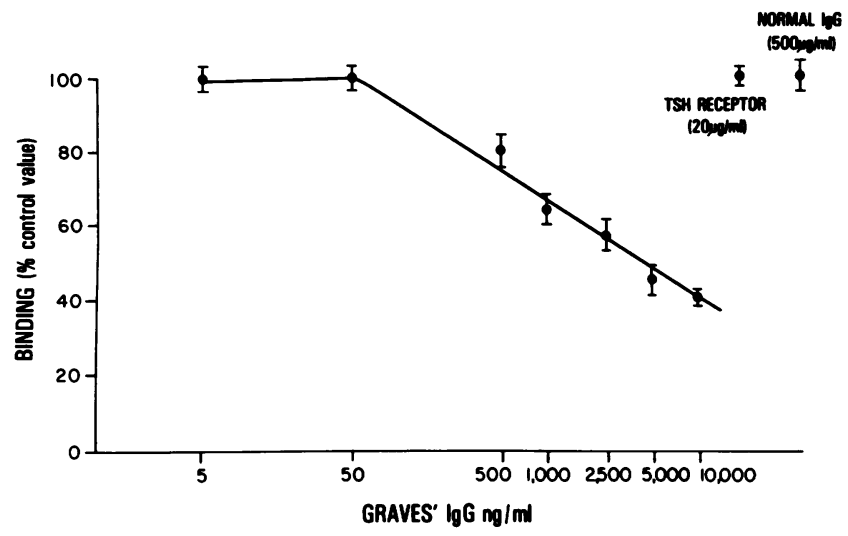

Figure 2. Inhibition of binding of anti-id to TSH by the addition of TSH receptor-purified Graves' IgG. Assayed binding of anti-id to solid-phase bovine TSH yielded reproducible values of $100 \pm 4 \%$ (SD) without inhibitor. The addition of TSH receptor-purified antibodies to the anti-id caused a progressive decrease in binding to a level of $40 \pm 3 \%$ of control value at the highest anti-id concentration that was attained $(10 \mu \mathrm{g} / \mathrm{ml}, P<0.001)$. Controls of normal IgG $(500 \mu \mathrm{g} / \mathrm{ml})$ and TSH receptor $(20 \mu \mathrm{g} / \mathrm{ml})$ had no effect on binding, and no inhibition was noted when similar concentrations of receptor-purified IgG were preincubated with TSH before the addition of anti-id.

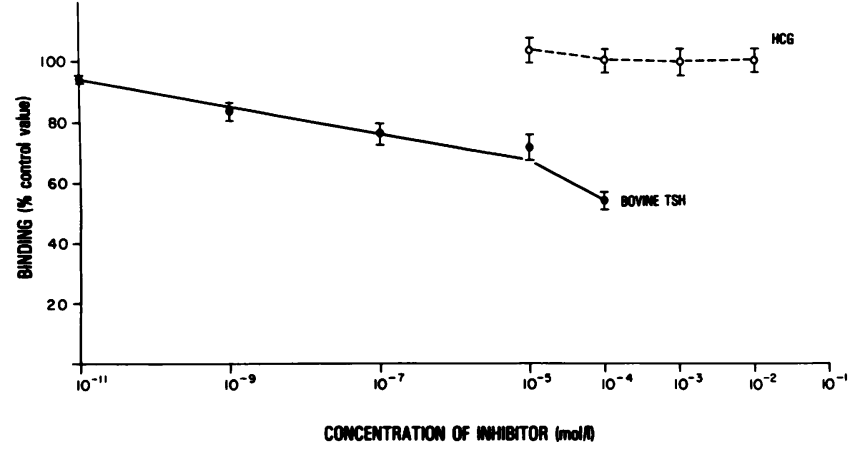

Figure 3. Inhibition of binding of anti-id to TSH receptor-purified Graves' IgG by the addition of bovine TSH. Assayed binding of antiid to solid phase, receptor-purified Graves' IgG gave consistent values of $100 \pm 3 \%$ without inhibitor. The addition of bovine TSH caused progressive inhibition of binding to $54 \pm 2 \%$ of control value at a TSH concentration of $10^{-4} \mathrm{M},(P<0.001)$. HCG at a concentration of $10^{-2} \mathrm{M}$ and preincubation of TSH with solid-phase receptor before the addition of anti-id had no effect on binding.

receptor caused the progressive inhibition of receptor binding, to $60 \%$ of control at an anti-id concentration of $1 \mu \mathrm{g} / \mathrm{ml}(P$ $<0.002$, Fig. $4 A$ ). Anti-human kappa and lambda antisera had a similar effect on binding, but only at an IgG concentration of $1 \mathrm{mg} / \mathrm{ml}$, which was 1,000 -fold greater than the concentration of rabbit anti-id that was required to cause similar inhibition. Also, normal rabbit IgG at $1 \mathrm{mg} / \mathrm{ml}$ had no effect on the binding (Fig. $4 \mathrm{~A}$ ). Control wells that were run with alkaline phosphataselabeled anti-rabbit IgG showed no evidence of the anti-id binding to solid-phase receptor (data not shown), which ruled out antiid receptor binding as the cause of inhibition. In comparison, preincubation of rabbit anti-id had no effect on the binding of Graves' serum to solid phase, anti-human $\mathrm{F}\left(\mathrm{ab}^{\prime}\right)_{2}$ (Fig. $4 \mathrm{~B}$ ), while anti-kappa/lambda showed suppression at a lower concentration than was required to block receptor binding ( $40 \mu \mathrm{g} /$ $\mathrm{ml}$ vs. $1 \mathrm{mg} / \mathrm{ml}$ ). Preincubation of anti-id with receptor and incubation with $3.5 \mathrm{M}$ sodium thiocyanate (data not shown) also had no effect on the binding of Graves' sera to TSH receptor.

Inhibition of TSH-mediated adenylate cyclase production by rabbit anti-id. Anti-id showed a progressive inhibition of cyclic-AMP production to $20 \%$ of control at a concentration of $0.5 \mu \mathrm{g} / \mathrm{ml}$ (Fig. 5). Commercial, heterologous rabbit anti-TSH had no effect at similar rabbit IgG concentrations. Sodium thiocyanate was measured in the dialyzed anti-id fraction and found to be $<1.5 \mathrm{mg} / \mathrm{l}$, a concentration which does not alter TSH stimulated adenylate cyclase.

Inhibition of multiple Graves' patient's sera binding to TSH receptor. Six Graves' sera (not including the patients' sera against which the anti-id was developed) were examined in the receptorbinding assay. All six showed inhibition of receptor binding upon the addition of rabbit anti-id at a concentration of $1 \mu \mathrm{g} /$ $\mathrm{ml}$ (Fig. 6). This inhibition ranged from 46 to 84\%. Preimmune rabbit IgG and rabbit IgG from animals that were immunized 
INHIBITION OF GRAVES' IgG BINDING TO TSH RECEPTOR AND TO ANTI HUMAN $F\left(a b^{\prime}\right)_{2}$ BY ANTI-IDIOTYPE AND ANTI HUMAN $K / \lambda$

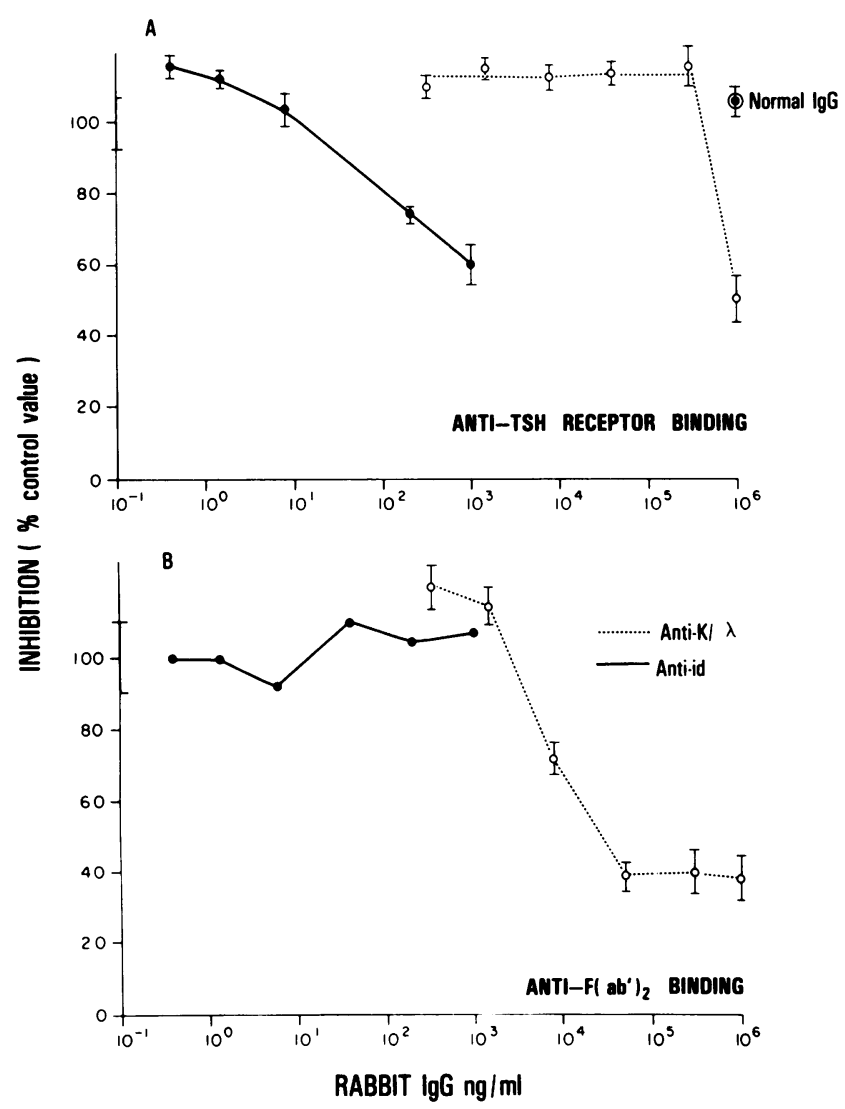

Figure 4. Comparative inhibition of Graves' IgG binding to TSH receptor and anti-human $F\left(a^{\prime}\right)_{2}$ by anti-id (solid line) and anti-kappa/ lambda (Anti- $\kappa / \lambda)$ antiserum (dotted line). The addition of anti-id to Graves' IgG resulted in a progressive inhibition of binding to receptor, to a level $60 \pm 4 \%$ of control value ( $100 \pm 5 \%$ without inhibitor) at a rabbit $\mathrm{IgG}$ concentration of $1 \mu \mathrm{g} / \mathrm{ml}(P<0.002)$. The same concentrations of anti-id had no effect on the binding of Graves' IgG to anti-human $F\left(a b^{\prime}\right)_{2}$. Anti- $\kappa / \lambda$ antiserum also inhibited binding of Graves' IgG to receptor, but required a concentration of $1 \mathrm{mg} / \mathrm{ml}$ for $60 \%$ inhibition $(P<0.001)$. It was capable of blocking binding of Graves' IgG to anti-human $F\left(a b^{\prime}\right)_{2}$ to a level of $20 \pm 4 \%$ of control value at a concentration of only $10 \mu \mathrm{g} / \mathrm{ml}(P<0.001)$, a 100 -fold lower concentration than that required to block receptor binding.

with myosin in complete Freund's adjuvant had no effect (data not shown) on Graves' IgG binding to GPF.

\section{Discussion}

The central hypothesis of the etiology of the hyperthyroidism of Graves' disease is auto-antibody-induced thyroid stimulation, although the events that initiate production of such an autoantibody are unknown. It has been previously shown that Graves'
INHIBITION OF TSH INDUCED C-AMP PRODUCTION BY ANTI-Id

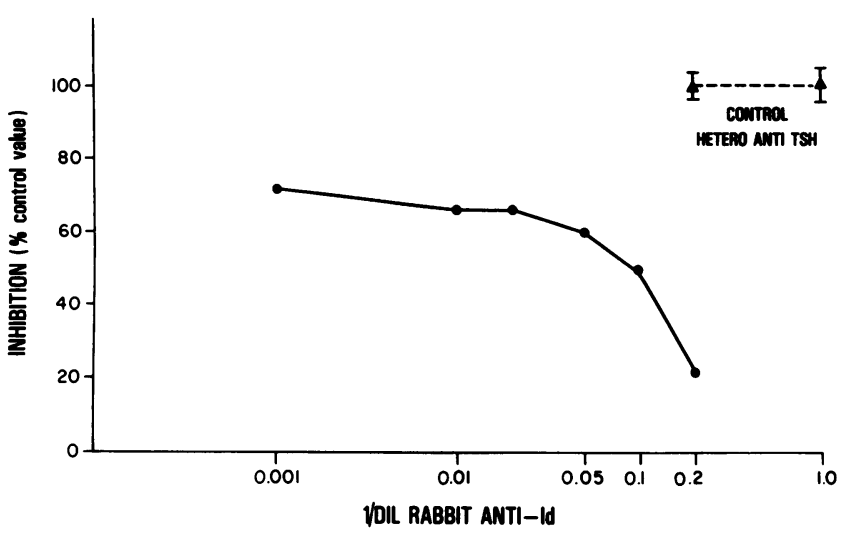

Figure 5. Inhibition of in vitro, TSH-mediated adenylate cyclase production by anti-id. The addition of progressive greater concentrations of anti-id to TSH caused an inhibition of adenylate cyclase production to a level $20 \%$ of control value. No effect was shown by 20 -fold greater concentrations of heterologous anti-TSH, or preimmune sera (not shown).

patients' immunoglobulin can block binding of radiolabeled TSH to receptor $(2,20,21)$ and can stimulate adenyl cyclase production in a system that contains TSH receptors $(3,19,22)$, which suggests action parallel to that of TSH. However, the biological activity of Graves' immunoglobulin on the thyroid gland is not identical to that of TSH, with time (23) and functional (24) differences that call into question the site and mode of action. The studies presented here give support to the theory that the antibody actually binds to the TSH receptor and causes stimulation of the gland. The finding that the Rbabs demonstrated enough conformational similarity to TSH to give rise to anti-id antibodies which bind to TSH, suggests that Rbabs recognize the receptor in the same manner as TSH. Also, antiid antibodies not only bound TSH, but also specifically blocked the production of thyroidal adenylate cyclase, which suggests that the portion of the Rbabs resembling TSH is that portion which is involved in binding or activation of the receptor. Heterologous anti-TSH antiserum did not inhibit adenylate cyclase production in equimolar concentrations to the anti-id; this may reflect the fact that these antibodies were raised against the whole TSH molecule (including portions that were not involved in receptor binding and activation), which supports the specificity of the binding of the anti-id.

The stimulatory activity of Graves' IgG has previously been shown to reside in the $F\left(a b^{\prime}\right)_{2}$ portion of the immunoglobulin, both by actual stimulation with $F(a b)$ fragments (4) and by the inhibition of stimulatory activity with anti-kappa/lambda antisera $(25,26)$. Our results support this hypothesis, as both antikappa/lambda antisera and anti-id (raised against $F\left(a b^{\prime}\right)_{2}$ determinants) were able to inhibit receptor binding. However, the fact that anti-id specifically inhibited binding to the TSH receptor but had no effect on the binding of the same antibody to anti- 


\section{INHIBITION OF SIX GRAVES' PATIENT'S TSH RECEPTOR BINDING BY ANTI-Id}

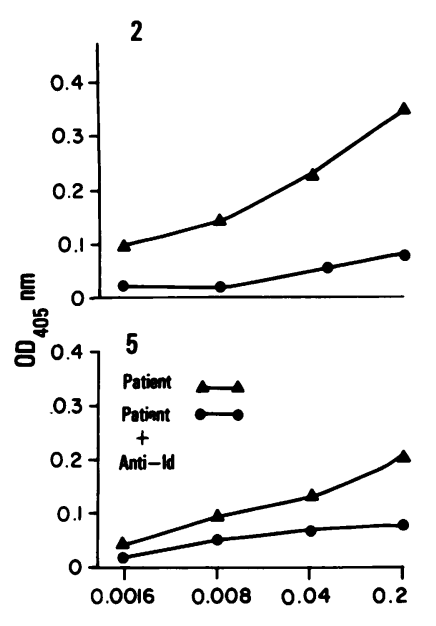

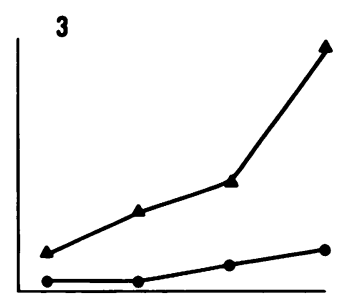

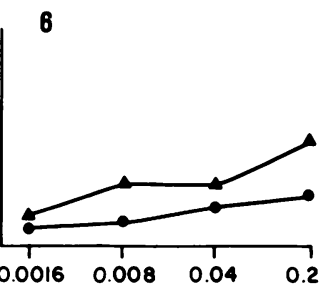

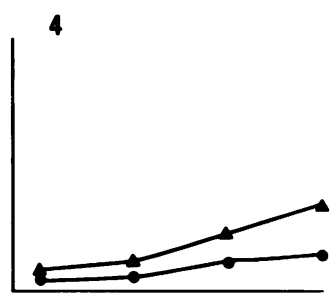

7

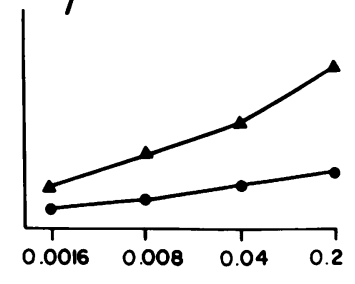

Figure 6. Binding of six different Graves' patients' IgG to TSH receptor (triangles) and inhibition by the addition of anti-id $(1 \mu \mathrm{g} / \mathrm{ml}$ final concentration, closed circles) at four different IgG concentrations. All patients showed flattening of their binding curves with the addition of anti-id, and had at least a $46 \%$ inhibition of binding at the highest Graves' patients' IgG concentrations.
$F\left(a b^{\prime}\right)_{2}$ antisera suggests that the anti-id antiserum is binding to antigens on the $F\left(a^{\prime}\right)_{2}$ region that are not commonly found on antibodies. These antigens are most likely in the area of the hypervariable region, since adsorption of the antisera with the pooled immunoglobulin column would remove antibodies against allotypic determinants.

Recently, it has been shown that anti-id antibodies to antiTSH antibodies have the capability of binding to the TSH receptor and causing stimulation (27). Similar studies have been performed using acetyl-choline (5), beta adrenergic (8), insulin (28), and F-met-leu-phe (29) receptors. Islam et al. (27) have suggested than an antibody response to TSH may be the initiating event in Graves' disease, with the Rbabs being anti-id antibodies that develop in response to the anti-TSH (11). This is unlikely, in our view, for a number of reasons. Firstly, anti-TSH antibodies have only been reported in a fraction of patients with Graves' disease, and in low titer (30), while Rbabs are present in $90 \%$ of Graves' patients, and often persist in high titer throughout the course of the disease $(3,31-34)$. Results with other systems have indicated that the primary response that is required to produce an anti-id is substantial, and while the primary antibody response tends to persist, the anti-id of normal immune responses appears to be short lived (35). Secondly, there are multiple epitopes on the TSH molecule, and only a fraction of which are involved in receptor binding and activation. Thus, the antiid response to anti-TSH that resulted in the prolonged production of Rbabs would be directed against only a small fraction of the antibodies that were produced against TSH. In contrast, the ability of the receptor to produce a primary immune response has been shown $(8,28,36)$, and our work indicates that the anti-TSH antibodies that is found in Graves' patients may be the result of an anti-id response to Rbabs. Although our data can support either point of view, we currently support the concept that production of Rbabs may be the primary immunological event in Graves' disease.

The inhibition of multiple Graves' patients' antibody binding to the TSH receptor with anti-id that was raised against only a single patient's Rbabs is of possible clinical importance. Recent studies have shown potential usefulness for anti-id antibodies as antigen-specific immunosuppressive agents (37-39). However, in complex antigen systems, such as tetanus toxoid, crossreactivity between idiotypes of different patients may not occur (40). This lack of crossreactivity may be the result of anti-id that recognize genetic or regulatory determinants on the immunoglobulin, and has also been implied in myasthenia gravis (41), an antigenic system which is presumptively similar to that in Graves' disease. The potential usefulness of anti-id for antigenspecific immunosuppression is limited by the need to produce specific, anti-id antisera for each patient. Our results demonstrating crossreactivity remove this limitation, and are in concordance with findings in such diverse antigen systems as Hepatitis B (42), rheumatoid factor (43), p-azophenylarsonate (44), and more recent studies with acetylcholine receptor (45). The findings of crossreactivity and an anti-id that conformationally appears to be the "internal image" of antigen places this anti-id in the second class of a recently proposed system for categorizing anti-ids $(46,47)$, and implies a common, antigenic determinant for the Rbabs binding site.

In conclusion, this work demonstrates that a common idiotype exists in Graves' disease, which has an "internal image" that appears to be similar to TSH. However, despite reiterating the "internal image" concept of antibody antigen interaction that was first proposed by Jerne (48), our studies cannot determine whether there are different "internal images" of Rbabs that interact with different TSH binding sites in the TSH receptor. This differentiation is important because of the report of multiple 
epitopes in the TSH receptor that have different functional activity (49). These questions might be clarified by application of the techniques we have developed to monoclonal or human anti-id systems.

\section{Acknowledgments}

The authors are grateful to Dr. Melvin Burger and Dr. Leonard Wartofsky for helpful suggestions and criticisms. S. P. Tucci, S. P. Yubetta, and Mr. Fred Coleman kindly helped with the rabbit care and handling. Mrs. Estelle Coleman provided expert secretarial assistance.

\section{References}

1. Strakosch, C. R., B. E. Wenzel, V. V. Row, and R. Volpé. 1982. Immunology of autoimmune thyroid diseases. N. Engl. J. Med. 307:14991507.

2. Smith, B. R., and R. Hall. 1974. Thyroid-stimulating antibodies in Graves' disease. Lancet. II:427-431.

3. Zakarija, M., J. M. McKenzie, and K. Banovac. 1980. Clinical significance of thyroid-stimulating antibody in Graves' disease. Ann. Intern. Med. 93:28-32.

4. Kriss, J. P., V. Pleshukov, A. Rosenblum, and J. R. Chien. 1965. Studies on the formation of long-acting thyroid stimulation immunoglobulin and the alteration of its biological activity by enzymatic digestion and partial chemical degradation. Curr. Top. Thyroid Res. Proc. Int. Thyroid Conf. 433-444.

5. Wasserman, N. H., A. S. Penn, P. I. Freimuth, N. Trepton, S. Wentzel, W. L. Cleveland, and B. F. Erlanger. 1982. Anti-idiotypic route to anti-acetylcholine receptor antibodies and experimental myasthenia gravis. Proc. Natl. Acad. Sci. USA. 79:4810-4814.

6. Piatier-Tonneau, D., B. Boger, P. Defre, and D. J. Charron. 1983. Syngenetic anti-idiotypes against monoclonal anti-HLA-DR antibodies: characterization of recurrent idiotopes. J. Immunol. 131:1339-1343.

7. Iverson, G. M., D. Eurdley, C. A. Janeway, and R. K. Gershon. 1983. Use of anti-id immunosorbents to isolate circulating antigen specific T cell-derived molecules from hyperimmune sera. Proc. Natl. Acad. Sci. USA. 80:1435-1439.

8. Schreiber, A. B., P. O. Conraud, C. Andre, B. Vray, and A. D. Strosberg. 1980. Anti-alprenolol anti-idiotypic antibodies bind to $\beta$-adrenergic receptors and modulate catecholamine-sensitive adenyl cyclase. Proc. Natl. Acad. Sci. USA. 77:7385-7390.

9. Homcy, C. J., S. G. Rockson, and E. Haber. 1982. An antiidiotype that recognizes the $\beta$-adrenergic receptor. J. Clin. Invest. 69:1147-1153.

10. Abdou, N. I., H. Wall, H. B. Lindsley, J. F. Halsey, and T. Suzuki. 1981. Network theory in autoimmunity: in-vitro suppression of serum anti-DNA antibody binding to DNA by anti-idiotypic antibody in systemic lupus erythematosis. J. Clin. Invest. 67:1297-1304.

11. Beall, G. N., and S. R. Kruger. 1983. Binding of ${ }^{125}$ I-human TSH by gamma globulins of sera containing thyroid-stimulating immunoglobulins. Life Sci. 32:77-83.

12. Neilson, E. G., and S. M. Phillips. 1982. Suppression of intensified nephritis by auto-anti-idiotypic immunity. J. Exp. Med. 155:179-189.

13. Dorrington, K. J., and D. S. Munro. 1965. Immunologic studies on long-acting thyroid stimulator. Clin. Sci. (Lond.). 28:165-174.

14. Bech, K. 1983. Immunologic aspects of Graves' disease and importance of thyroid stimulating immunoglobulins. Acta Endocrinol. Suppl. 254. 103:1-38.
15. Schleusener, H., D. Kotulla, R. Finke, H. Sorje, H. Meinhold, F. Adelkofer, and K. W. Wenzel. 1978. Relationship between thyroid status and Graves' disease specific immunoglobulins. J. Clin. Endocrinol. Metab. 47:379-384.

16. Baker, J. R., Jr., Y. G. Lukes, R. C. Smallridge, M. Berger, and K. D. Burman. 1983. Partial characterization and clinical correlation of circulating human immunoglobulins directed against thyrotropin binding sites in guinea pig fat cell membranes. J. Clin. Invest. 72:14871497.

17. Endo, K., S. M. Amir, A. W. Peterson, and S. H. Ingbar. 1974. Development and evaluation of a method for the partial purification of immunoglobulins specific for Graves' disease. J. Clin. Endocrinol. Metab. 52:1113-1123.

18. Volkman, D. J., H. C. Lane, and A. S. Fauci. 1981. Antigeninduced in vitro antibody production by humans: a model for B cell activation and immuno-regulation. Proc. Natl. Acad. Sci. USA. 78:25282535.

19. Kleinmann, R. E., L. E. Braverman, A. Vagenakis, R. W. Butcher, and R. B. Clark. 1980. A new method for measurement of human thyroid-stimulating immunoglobulins. J. Lab. Clin. Med. 95:581-589.

20. Sugenoya, A., A. Kidd, V. V. Row, and R. Volpé. 1979. Correlation between thyrotropin-displacing activity and human thyroidstimulating activity by immunoglobulin from patients with Graves' disease and other disorders. J. Clin. Endocrinol. Metab. 48:398-402.

21. Teng, C. S., B. R. Smith, B. Clagton, D. C. Evered, F. Clark, and R. Hall. 1977. Thyroid stimulating immunoglobulins in ophthalamic Graves' disease. Clin. Endocrinol. Metab. 6:207-211.

22. Bech, K., and N. S. Madsen. 1979. Thyroid adenylate cyclase stimulating immunoglobulins in thyroid diseases. Clin. Endocrinol. (Metab.). 11:47-58.

23. Adams, D. D., and H. D. Purves. 1956. Abnormal responses in the assay of thyrotrophin. Proc. Univ. Otago Med. Sch. 34:11-12.

24. Zakarija, M., J. M. McKenzie, and D. S. Munro. 1983. Immunoglobulin $G$ inhibition of thyroid-stimulating antibody is a cause of delay in the onset of neonatal Graves' disease. J. Clin. Invest. 72:13521356.

25. Kriss, J. P. 1968. Inactivation of long-acting thyroid stimulation by anti-kappa and anti-lambda antisera. J. Clin. Endocrinol. Metab. 28:1440-1444.

26. Smith, B. R., D. S. Munro, and K. J. Dorrington. 1969. The distribution of the long-acting thyroid stimulator among gamma G-immunoglobulins. Biochim. Biophys. Acta. 188:89-100.

27. Islam, M. N., B. M. Pepper, R. Briones-Urbina, and W. R. Farid. 1983. Biological activity of anti-thyrotropin anti-idiotypic antibodies. Eur. J. Immunol. 13:1357-63.

28. Schecter, Y., R. Mason, D. Elias, and I. R. Cohen. 1982. Autoantibodies to insulin receptor spontaneously develop as anti-idiotypes in mice immunized with insulin. Science (Wash. DC). 216:542-545.

29. Marasco, W. A., and E. L. Becker. 1982. Anti-idiotype as antibody against the formyl peptide chemotaxis receptor of the neutrophil. $J$. Immunol. 128:963-968.

30. Biro, J. 1982. Thyroid-stimulating antibodies in Graves' disease and the effect of thyrotropin-binding globulins on their determination. J. Endocrinol. 92:175-184.

31. Fenzi, G., K. Hashizume, C. P. Roudebush, and L. J. DeGroot. 1979. Changes in thyroid-stimulating immunoglobulins during antithyroid therapy. J. Clin. Endocrinol. Metab. 48:572-576.

32. Teng, C. S., and R. T. T. Yeung. 1980. Changes in thyroid stimulating antibody activity in Graves' disease treated with anti-thyroid 
drugs and its relationship to relapse: a prospective study. J. Clin. Endocrinol. Metab. 50:144-147.

33. Teng, C. S., R. T. T. Yeung, H. K. K. Khoo, and T. T. Alagaratnan. 1980. A prospective study of the changes in thyrotropin binding inhibitory immunoglobulins in Graves' disease treated by subtotal thyroidectomy or radioactive iodine. J. Clin. Endocrinol. Metab.1 50:10051010.

34. Wood, L. C., and S. H. Ingbar. 1979. Hypothyroidism as a late sequela in patients with Graves' disease treated with antithyroid agents. J. Clin. Invest. 64:1429-1436.

35. Geha, R. S. 1982. Presence of auto anti-idiotypic antibody during the normal immune response to tetanus. J. Immunol. 139:139-144.

36. Burman, K. D., Y. Y. Djuh, and J. R. Baker, Jr. 1983. Beta ligand antibodies in rabbits immunized with beta adrenergic receptors and in the serum of patients with auto-immune thyroid disease. Prog. 59th Ann. Meet. Am. Thyroid Ass., New Orleans. T65. (Abstr.)

37. Olson, J. C., C. R. Wagner, and G. A. Leslie. 1982. The assessment of anti-idiotypic antibodies as effective immunoregulator probes in vivo. Clin. Exp. Immunol. 48:458-468.

38. Miller, G. G., P. I. Nadler, R. J. Hodes, and D. H. Sachs. 1982. Modification of $T$ cell anti-nuclease idiotype expression by in vivo administration of anti-idiotype. J. Exp. Med. 155:190-200.

39. Bona, C. A., S. Finley, S. Waters, and H. G. Kunkel. 1982. Antiimmunoglobulin antibodies. J. Exp. Med. 156:986-999.

40. Geha, R. S., and R. P. Weinberg. 1978. Anti-idiotypic antisera in man. J. Immunol. 121:1518-1523.

41. Barkas, T., and J. A. Simpson. 1982. Lack of inter-animal crossreaction of anti-acetylcholine receptor antibodies at the receptor-binding site as demonstrated by heterologous anti-idiotype on antisera: implications for immunotherapy of myasthenia gravis. Clin. Exp. Immunol. 47:119-126.

42. Kennedy, R. C., and G. R. Dresman. 1983. Common idiotypic determinant associated with human antibodies to hepatitis B surface antigen. J. Immunol. 130:385-389.

43. Fong, S., T. A. Gilbertson, and D. A. Carson. 1983. The internal image of IgG in cross-reactive anti-idiotypic antibodies against human rheumatoid factors. J. Immunol. 131:719-724.

44. Hornbeck, P. V., and G. K. Lewis. 1983. Idiotype connectance in the immune system. J. Exp. Med. 157:1116-1136.

45. Lefvert, A., R. W. James, C. Alliod, and B. W. Fulpins. 1982. A monoclonal anti-idiotypic antibody against anti-receptor antibodies from myasthernic sera. Eur. J. Immunol. 12:790-792.

46. Bona, C., and J. Hiernaux. 1981. Immune response: idiotypes and anti-idiotype network. CRC Crit. Rev. Immunol. 2:33.

47. Nisonoff, A., and E. Lanozi. 1981. Implications of the presence of an internal image of the antigen or anti-idiotypic antibodies: possible application of vaccine production. Clin. Immunol. Immunopathol. 21:397-406.

48. Jerne, N. K. 1974. Towards a network theory of the immune system. Ann. Immunol. (Paris). 125:373-389.

49. Valente', W. A., P. Vitti, Z. Yavin, E. Yavin, C. M. Rotella, E. F. Grollman, R. S. Toccafondi, and L. D. Kohn. 1982. Monoclonal antibodies to the thyrotropin receptor: stimulating and blocking antibodies derived from the lymphocytes of patients with Graves' disease. Proc. Natl. Acad. Sci. USA. 79:6680-6684. 